\begin{tabular}{|c|c|c|}
\hline ב & $\begin{array}{l}\text { International Journal of Current Research in } \\
\text { Biosciences and Plant Biology }\end{array}$ & $y=$ \\
\hline & Volume 7 • Number 11 (November-2020) • ISSN: 2349-8080 (Online) & \\
\hline $\begin{array}{l}\text { EXCELLENT } \\
\text { PUBLISHERS }\end{array}$ & Journal homepage: www.ijcrbp.com & \\
\hline
\end{tabular}

\title{
Comparative assessment of sucrose, 8-hydroxyquinoline and 5 -sulfosalicylic acid in the regulation of petal senescence in cut scapes of Aster novae belgii L., Matricaria parthenium L. and Gaillardia pulchella Foug.
}

\author{
Mansee Khokhar'1, Shubhankar Mukherjee² and Dibakar Mukherjee1* \\ ${ }^{1}$ Department of Botany, Kurukshetra University, Kurukshetra - 136119, India \\ ${ }^{2}$ The Institute of Integrated \& Honors Studies, Kurukshetra University, Kurukshetra - 136119, India \\ *Corresponding author; e-mail: dibumukherjee@gmail.com
}

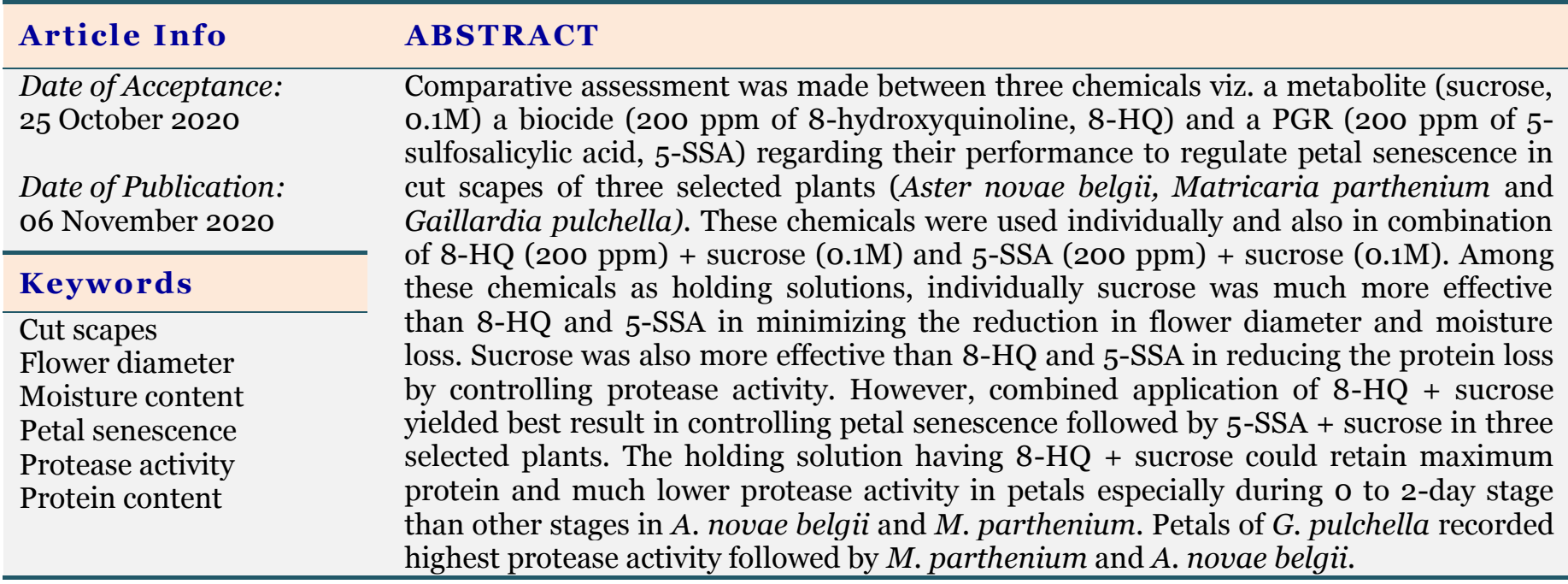

\section{Introduction}

Senescence is a developmental process in all plants that starts after maturity. Various deteriorative changes viz. morphological, physiological and biochemical are witnessed at the onset of senescence. These changes shorten the functional life of plants and plant organs (Woolhouse, 1967; Beevers, 1976). In case of flowers or floral inflorescence, senescence begins after their complete development when they show the sign of wilting and abscission of whole flowers or flower parts (Stead and van Doorn, 1994). Cut flowers may be defined as flowers or an inflorescence containing more than one floral unit in the opened or unopened state which are harvested and marketed for ornamental purpose. Cut flowers and cut scapes (flowering twig from which leaves have been removed) experience very rapid loss of freshness and turgidity than attached flowers as the supply of water and nutrients becomes a limiting factor in the former. The breakdown of 
proteins, carbohydrates and lipids and decrease in nucleic acids are most common features of flower senescence (van Doorn and Woltering, 2008; Khokhar et al. 2018). It is also characterized by rapid increase in lipid peroxidation, membrane leakage and breakdown of cell wall components (Buchanan - Wollaston, 1997).

Flower quality can be maintained and vase life can be extended by sugars like sucrose as they are carbon and energy source (Kuiper et al., 1995; Monteiro et al., 2002; van Doorn, 2004; Mukherjee and Mukherjee, 2017). When present in the vase solution, sucrose increases the osmotic concentration of petal cell sap and maintain turgidity in cut flowers (O'Donoghue et al., 2002). Sugars are also known to delay petal senescence by suppressing ethylene synthesis, which is a naturally occurring plant growth regulator (PGR) as opined by Woltering and van Doorn, 1988).

PGRs like abscisic acid (ABA), auxins, cytokinins, gibberellins, morphactins, salicylic acid, polyamines, etc. are also involved in the regulation of petal senescence (Kaur et al., 2017; Khokhar et al. 2018). Unlike cytokinins and some other PGRs, fewer studies have been carried out with 5sufosalicylic acid (5-SSA) which is derived from salicylic acid (SA). SA is an important endogenous PGR which not only enhances flowering (Raskin, 1992) but also delays flower senescence (Kaur et al., 2017). The vase life of cut Gladiolus flowers was extended in presence of 5-SSA (Ezhilmathi et al., 2007). This treatment increased significantly solution uptake and number of opened florets; and lowered lipid peroxidation and lipoxygenase activity. It also increased membrane stability, soluble protein content and activities of superoxide dismutase (SOD) and catalase in comparison to controls. Experiments with cut scapes and cut flowers face the danger of microorganism invasion at the cut surface. Flow of holding solutions (water, nutrient solution, PGR, etc.) is slowed down due to bacterial multiplication and synthesis of extra cellular polysaccharides within the vessels. Release of pectinases and toxic compounds are also responsible for ethylene synthesis which in turn accelerates flower senescence (Jowkar et al., 2012).

Biocides like 8-hydroxyquinoline (8-HQ), 8hydroxyquinoline citrate (8-HQC) and 8hydroxyquinoline sulphate (8-HQS) are often used to prevent microbial attack. This property of biocides makes them very useful in floriculture industry. Working with cut roses, van Doorn and Perik (1990) have reported their effectiveness in lowering $\mathrm{pH}$ of the holding solution and preventing vascular blockage. Combined treatment of sucrose + 8-HQC+GA could extend the longevity of cut lily flowers (Rabiza - Swider et al., 2012).

Based upon above facts regarding the utility of sucrose, 5-SSA and 8-HQ representing a metabolite, a PGR and a biocide it was thought to undertake an investigation where one could assess their importance individually and in combination of two (5-SSA + sucrose and 8-HQ + sucrose) in relation to petal senescence of cut scapes. Furthermore, this study tried to assess effectiveness of these substances in three plants viz. Aster novae belgii, Matricaria parthenium and Gaillardia pulchella selecting some important paramenters like flower diameter, moisture content, absorption of holding solution, protein content and protease activity.

\section{Materials and methods}

\section{Plant material}

Three plants viz. Aster novae belgii L., Matricaria parthenium L. and Gaillardia pulchella Foug. were selected in the present investigation. Saplings were raised from the certified seeds of above plants in uniformly prepared experimental plots within wire net cage in the garden of Botany Department. Plants were allowed to grow and flower. At the time of flowering, cut flowers were harvested in the morning hours with a sharp scalpel. Flower twigs were cut in a bucket filled with water to prevent cavitation and were brought to the laboratory immediately. Leaves were removed from the cut flower twigs to have cut scapes which were put in the conical flasks containing different holding solutions already prepared.

\section{Holding solutions and experimental set up}

Holding solutions used here include 5-SSA (200 ppm), 8-HQ (200 ppm), sucrose (o.1M), 5-SSA $(200 \mathrm{ppm})+$ sucrose $(0.1 \mathrm{M}), 8-\mathrm{HQ}(200 \mathrm{ppm})+$ sucrose (o.1M). Double distilled water (DDW) as a separate holding solution was also kept as a control set. For each holding solution, 10 conical flasks of 
Borosil glass of $100 \mathrm{ml}$ volume were used. Three scapes of $14 \mathrm{~cm}$ length were introduced in each flask having $30 \mathrm{ml}$ of specific holding solution. Untreated control sets were similarly prepared. All experiments were set up at room temperature under day and night light intensity of $2.24 \mu \mathrm{mol} \mathrm{m} \mathrm{m}^{-}$

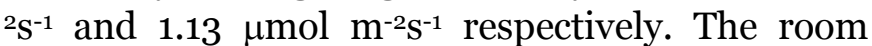
temperature for cut scapes experiment with $A$. novae belgii and $M$. parthenium was $25 \pm 2^{\circ} \mathrm{C}$ while that of G.pulchella was $37 \pm 2{ }^{\circ} \mathrm{C}$.

\section{Samplings}

Samples were collected at o, 2, 4 and 6-day stages from petals of all cut scapes maintained in different holding solutions. Samples were made in such a manner that 3 replicates were available for each biochemical analysis. For collecting dry weight data triplicate samples were placed in the oven for 2 days at $80^{\circ} \mathrm{C}$. Various observations such as visible effect, longevity, volume of holding solutions absorbed, moisture content and flower diameter were also recorded at specific time. These data are based upon mean of 10 replicates.

\section{Extraction and estimation of protein}

The method of extraction of protein has been described earlier (Singh et al., 2018). Protein content was estimated by the method of Bradford (1976) using Coomassie Brilliant blue G-250. The quantity of protein was calculated against a standard curve of bovine serum albumin (BSA, Sigma, USA).

\section{Protease activity}

The original method was described by Yemm and Cocking (1955) followed by its modification by Reimerdes and Klostermeyer (1976). One hundred milligram of petal sample was homogenized in 100 $\mathrm{mM}$ phosphate buffer ( $\mathrm{pH}$ 7.2) and the final volume was raised to $10 \mathrm{ml}$. One percent casein (Sigma, USA) was prepared by dissolving $1 \mathrm{gm}$ of casein in minimal volume (0.4 to $0.8 \mathrm{ml}$ ) of $0.1 \mathrm{~N}$ $\mathrm{NaOH}$ followed by raising the final volume to 100 $\mathrm{ml}$ with $100 \mathrm{mM}$ phosphate buffer ( $\mathrm{pH}$ 7.6). To 1 $\mathrm{ml}$ of casein $1 \mathrm{ml}$ of enzyme extract was added and incubated for $3 \mathrm{hrs}$ at $37^{\circ} \mathrm{C}$. The $\mathrm{pH}$ of the reaction mixture was 7.5. One $\mathrm{ml}$ of boiled enzyme was taken in blank set to which $1 \mathrm{ml}$ of casein and $1 \mathrm{ml}$ of $10 \%$ trichloroacetic acid (TCA, $10 \mathrm{gm}$ in $100 \mathrm{ml}$ of distilled water) were added immediately to stop the reaction. The precipitate was then centrifuged. After incubation, $1 \mathrm{ml}$ of TCA added to all the reaction sets; centrifuged them again and discarded the residue. Out of the resultant $3 \mathrm{ml}$ filtrate $1 \mathrm{ml}$ was taken to estimate the enzymatic activity. Ninhydrin solution was prepared by dissolving $1.25 \mathrm{gm}$ of ninhydrin in $47 \mathrm{ml}$ of methyl cellosolve (2-methoxy ethanol) and to this $15.5 \mathrm{ml}$ of filtered solution of $\mathrm{SnCl}_{2}$ (100 mg in $4 \mathrm{~N}$ sodium acetate buffer, $25.01 \mathrm{ml}$; mentioned in next para) was added. The solution was collected in a dark bottle and stored in a refrigerator. To $1 \mathrm{ml}$ of enzyme solution $1 \mathrm{ml}$ of ninhydrin solution was added, mixed well and test tubes containing this mixture were placed in boiling water bath at $100^{\circ} \mathrm{C}$ for $15 \mathrm{~min}$. Test tubes were cooled thereafter and 2 $\mathrm{ml}$ of $50 \%$ ethanol was added in each tube. The resultant violet colour was read at $550 \mathrm{~nm}$ in a UVVis spectrophotometer. Specific activity of protease was expressed in terms of $\mu \mathrm{M}$ Lysine equivalent per $100 \mathrm{mg}$ dry weight of tissue $\mathrm{hr}^{-1}$.

\section{Preparation of 4 N Sodium Acetate buffer}

Stock solution number 1 ( $4 \mathrm{~N}$ sodium acetate) was prepared by dissolving $5.44 \mathrm{gm}$ of sodium acetate (hydrated, $3 \mathrm{H}_{2} \mathrm{O}$ ) in double distilled water (DDW) and the volume of solution was raised to $1000 \mathrm{ml}$. A volume of $228.56 \mathrm{ml}$ of glacial acetic acid was raised to $1000 \mathrm{ml}$ with DDW to make stock solution number 2 (4N glacial acetic acid). Now 25 $\mathrm{ml}$ of stock solution 1 was mixed with $0.01 \mathrm{ml}$ of stock solution 2. Thus we get $4 \mathrm{~N}$ solution of sodium acetate buffer of $\mathrm{pH} 4.8$.

\section{Statistical analysis}

The experiments were laid out in a completely randomised design and repeated twice with mostly three replicates. Flower diameter was based upon ten replicates. Analysis of variance (ANOVA) was performed and means were compared by the least significant difference $(\mathrm{P}=0.05)$.

\section{Results}

Flower diameter and moisture content of petals of Aster novae belgii L., Matricaria parthenium L. and Gaillardia pulchella Foug. have been presented in Table 1-3 when scapes were 
maintained in double distilled water, 5-sulfosalicylic acid (5-SSA, 200 ppm), 8-hydroxyquinoline (8-HQ, $200 \mathrm{ppm})$, sucrose (o.1M), 5-SSA (200 ppm) + sucrose (o.1M) and 8-HQ (200 ppm) + sucrose (01.M). A gradual decrease has been noticed in flower diameter of scapes belonging to three plants during 6-day. Maximum reduction was witnessed in untreated $A$. novae belgii petals followed by G. pulchella and $M$. parthenium. A comparison of 5-SSA and 8-HQ treated flower scapes with untreated ones revealed their effectiveness to check partially the reduction in flower diameter in all plants investigated. The use of sucrose (o.1 M) as holding solution was much better than either 5-SSA or 8-HQ application. It was indeed a better combination when sucrose was added to both 5-SSA and 8-HQ. Retention of flower diameter was the best with a combined application of 8-HQ + sucrose followed by 5 -SSA + sucrose in these cut scapes.

Table 1. Aster novae belgii L. showing changes in flower diameter and moisture content of petals when scapes were placed in various holding solutions (Double distilled water, DDW as control; 5-sulfo salicylic acid, 5-SSA, 200 ppm; 8-hydroxyquinoline, 8-HQ, 200 ppm; sucrose, 0.1M; 5-SSA, 200 ppm + sucrose, 01.M; 8-HQ, $200 \mathrm{ppm}+$ sucrose, $0.1 \mathrm{M}$ ). [o-Day values of flower diameter and moisture content were $6.9 \mathrm{~cm}$ and $80.10 \%$ respectively].

\begin{tabular}{lllll}
\hline Treatments & \multicolumn{2}{l}{ Flower diameter (in cm) } & \% Difference between \\
\cline { 2 - 5 } & 2-Day & 4-Day & 6-Day & o to 6-Day \\
\hline Control (DDW) & 5.1 & 4.2 & 2.1 & 69.57 \\
5-SSA & $5 \cdot 4$ & 4.6 & 2.3 & 66.67 \\
8-HQ & $5 \cdot 7$ & 4.8 & 2.5 & 63.77 \\
Sucrose & 6.1 & $5 \cdot 3$ & 2.8 & 59.42 \\
5-SSA+Sucrose & 6.5 & 5.7 & 3.0 & 56.52 \\
8-HQ + Sucrose & 6.8 & 5.9 & 3.5 & 49.28 \\
Moisture content (\%) & & & & \\
Control (DDW) & 67.40 & 60.15 & 54.29 & 25.81 \\
5-SSA & 69.32 & 61.23 & 55.17 & 24.93 \\
8-HQ & 70.14 & 62.51 & 55.46 & 24.64 \\
Sucrose & 74.22 & 64.30 & 57.28 & 22.82 \\
5-SSA+Sucrose & 77.54 & 66.73 & 59.11 & 20.99 \\
8-HQ+Sucrose & 79.21 & 67.00 & 59.75 & 20.35 \\
\hline Ea & & & \\
\hline
\end{tabular}

Each value indicates mean of 10 replicates.

Table 2. Matricaria parthenium L. showing changes in flower diameter and moisture content of petals when scapes were placed in various holding solutions (Double distilled water, DDW as control; 5-sulfosalicylic acid, 5-SSA, $200 \mathrm{ppm}$; 8-hydroxyquinoline, 8-HQ, $200 \mathrm{ppm}$; sucrose, 0.1M; 5-SSA, $200 \mathrm{ppm}+$ sucrose, 01.M; 8-HQ, $200 \mathrm{ppm}+$ sucrose, $0.1 \mathrm{M}$ ). [0-Day values of flower diameter and moisture content were $7.2 \mathrm{~cm}$ and $89.12 \%$ respectively].

\begin{tabular}{lllll}
\hline \multicolumn{1}{c}{ Treatments } & \multicolumn{2}{l}{ Flower diameter (in cm) } & \multicolumn{2}{l}{ \% Difference between } \\
\cline { 2 - 5 } & 2-Day & 4-Day & 6-Day & o to 6-Day \\
\hline Control (DDW) & 5.8 & 4.9 & 3.7 & 48.61 \\
5-SSA & 6.3 & 5.2 & $3 \cdot 9$ & 45.83 \\
8-HQ & 6.7 & $5 \cdot 4$ & 4.1 & 43.06 \\
Sucrose & 6.9 & $5 \cdot 5$ & 4.3 & 40.28 \\
5-SSA+Sucrose & 7.1 & $5 \cdot 7$ & 4.5 & 37.50 \\
8-HQ + Sucrose & 7.2 & 5.8 & 4.8 & 33.33 \\
Moisture content (\%) & & & & \\
Control (DDW) & 79.32 & 72.31 & 68.14 & 20.98 \\
5-SSA & 80.24 & 74.35 & 68.75 & 20.37 \\
8-HQ & 81.53 & 75.41 & 69.31 & 19.81 \\
Sucrose & 83.16 & 77.23 & 70.40 & 18.72 \\
5-SSA+Sucrose & 85.37 & 78.11 & 72.35 & 16.77 \\
8-HQ+Sucrose & 86.14 & 79.13 & 72.87 & 16.25 \\
\hline Each value indicates & & &
\end{tabular}


Table 3. Gaillardia pulchella Foug. showing changes in flower diameter and moisture content of petals when scapes were placed in various holding solutions (Double distilled water, DDW as control; 5sulfosalicylic acid, 5-SSA, $200 \mathrm{ppm}$; 8-hydroxyquinoline, 8-HQ, $200 \mathrm{ppm}$; sucrose, o.1M; 5-SSA, $200 \mathrm{ppm}+$ sucrose, 01.M; 8-HQ, $200 \mathrm{ppm}+$ sucrose, 0.1M). [0-Day values of flower diameter and moisture content were $5.2 \mathrm{~cm}$ and $75.14 \%$ respectively].

\begin{tabular}{lllll}
\hline \multirow{2}{*}{ Treatments } & \multicolumn{2}{l}{ Flower diameter (in cm) } & \multicolumn{2}{c}{ \% Difference between } \\
\cline { 2 - 5 } & 2-Day & 4-Day & 6-Day & o to 6-Day \\
\hline Control (DDW) & 4.3 & 3.1 & 1.9 & 63.46 \\
5-SSA & 4.5 & 3.4 & 2.4 & 53.85 \\
8-HQ & 4.6 & 3.6 & 2.6 & 50.00 \\
Sucrose & 4.7 & 4.0 & 3.0 & 42.31 \\
5-SSA+Sucrose & 4.9 & 4.2 & 3.1 & 40.38 \\
8-HQ + Sucrose & 5.1 & 4.3 & 3.2 & 38.46 \\
Moisture content (\%) & & & & \\
Control (DDW) & 67.22 & 59.33 & 50.00 & 25.14 \\
5-SSA & 67.75 & 59.88 & 50.25 & 24.89 \\
8-HQ & 68.16 & 60.14 & 50.16 & 24.98 \\
Sucrose & 70.35 & 62.37 & 52.22 & 22.92 \\
5-SSA+Sucrose & 73.14 & 64.44 & 53.14 & 22.00 \\
8-HQ+Sucrose & 73.95 & 65.12 & 53.76 & 21.38 \\
\hline Each value indicates mean of 10 replicates & & &
\end{tabular}

Percent moisture content was showing a gradual decline in petals of cut scapes during 6 days in all selected plants. The decline in percent moisture content in untreated petals of $A$. novae belgii, $M$. parthenium and G. pulchella was 25.81, 20.98 and 25.14 respectively during 6 days. Reduction in percent moisture content was also witnessed in the treated scapes of all these plants (Table 1-3). Petals of treated scapes exhibited slightly higher values of moisture content and the degree of effectiveness in retaining moisture was maximum in scapes having treatment of 8-HQ + sucrose $>5$-SSA + sucrose $>$ sucrose $>8-\mathrm{HQ}>5$-SSA $>$ control.
The volume of holding solution in each conical flask was $30 \mathrm{ml}$ when experiment was set up and the volume of absorbed solution has been shown after 6-day (Table 4). An increasing trend in absorption was noticed in all treated scapes in comparison to control. Maximum absorption was found when holding solution was 8-HQ + sucrose $>5$-SSA + sucrose > sucrose > 8-HQ > 5-SSA > control (DDW). Relatively larger absorption was witnessed by cut scapes of $A$. novae belgii and $G$. pulchella as compared to $M$. parthenium in both control and treated sets.

Table 4. Volume of holding solution absorbed (ml) scapes ${ }^{-3}$ of Aster novae belgii L., Matricaria parthenium L. and Gaillardia pulchella Foug during 6-Day when scapes were placed in various holding solutions (Double distilled water, DDW as control; 5-sulfosalicylic acid, 5-SSA, $200 \mathrm{ppm}$; 8-hydroxyquinoline, 8-HQ, 200 ppm; sucrose, o.1M; 5-SSA, $200 \mathrm{ppm}+$ sucrose, $0.1 \mathrm{M} ; 8-\mathrm{HQ}, 200 \mathrm{ppm}+$ sucrose, $0.1 \mathrm{M}$ ). [Volume of holding solution on $\mathrm{O}-\mathrm{Day}=30 \mathrm{ml}]$.

\begin{tabular}{llll}
\hline Treatments & $\begin{array}{l}\text { Volume of holding } \\
\text { solution } \text { A. novae } \\
\text { belgii }\end{array}$ & $\begin{array}{l}\text { Volume of holding } \\
\text { solution } M .\end{array}$ & $\begin{array}{l}\text { Volume of holding } \\
\text { parthenium }\end{array}$ \\
solution . pulchella \\
\hline Control (DDW) & 18.10 & 12.75 & 17.60 \\
5-SSA & 18.67 & 14.17 & 18.67 \\
8-HQ & 19.50 & 14.72 & 18.79 \\
Sucrose & 20.54 & 15.42 & 19.75 \\
5-SSA+Sucrose & 20.69 & 15.90 & 21.67 \\
8-HQ+Sucrose & 21.11 & 16.49 & 22.80 \\
\hline
\end{tabular}

Each value indicates mean of 10 replicates. 
Changes in the amount of protein and protease activity (in lysine equivalent) of petals from cut scapes of three selected plants have been incorporated in Table 5-7. The initial protein contents were $9.374 \mathrm{mg}, 11.042 \mathrm{mg}$ and $6.862 \mathrm{mg}$ per $100 \mathrm{mg}$ dry weight in $A$. novae belgii, $M$. parthenium and G. pulchella respectively. The protein quantity registered a steady decrease in untreated and treated petals of cut scapes. Treatments with 5-SSA, 8-HQ and sucrose, however, minimized the protein degradation in all selected plants. The holding solution containing 8$\mathrm{HQ}+$ sucrose was unique to retain maximum protein specially during 0-2 day stage in A. novae belgii and $M$. parthenium. Among individual treatments, maximum effectiveness was observed with sucrose followed by 8-HQ and 5-SSA.
Combined application was able to retain much higher protein than individual application in three plants studied. Unlike protein content, protease activity registered a steady increase from o to 6day in controls and treated petals belonging to three plants. Highest protease activity was witnessed in $A$. novae belgii followed by $M$. parthenium and G. pulchella initially but 6-day stage of untreated petals showed maximum activity in $M$. parthenium followed by $A$. novae belgii and G. pulchella. Holding solutions of sucrose, 8-HQ and 5-SSA could bring down the enzymatic activity appreciably resulting comparatively higher amount of protein. The combined applications of $8-\mathrm{HQ}+$ sucrose and 5-SSA + sucrose were again very effective in lowering the enzymatic activity in all these plants.

Table 5. Aster novae belgii L. showing changes in the amount of protein (mg / $100 \mathrm{mg}$ dry weight \pm S.E.) and protease activity ( $\mu \mathrm{M}$ Lysine equivalent / $100 \mathrm{mg}$ dry weight \pm S.E.) in petals when scapes were placed in various holding solutions (Double distilled water, DDW as control; 5-sulfosalicylic acid, 5-SSA, 200 ppm; 8hydroxyquinoline, 8-HQ, $200 \mathrm{ppm}$; sucrose, o.1M; 5-SSA, $200 \mathrm{ppm}+$ sucrose, 0.1M; 8-HQ, 200 ppm+sucrose, o.1M). [o-day values of protein and protease activity were 9.374 \pm 0.434 and $8.716 \pm 0.053$ respectively].

\begin{tabular}{|c|c|c|c|}
\hline Treatments & 2-Day & 4-Day & 6-Day \\
\hline \multicolumn{4}{|c|}{ Protein } \\
\hline Control (DDW) & $5.917 \pm 0.207^{\mathrm{aC}}(-36.878)$ & $4.463 \pm 0.393^{\mathrm{bB}}(-52.390)$ & $2.500 \pm 0.075^{\mathrm{cB}}(-73.330)$ \\
\hline 5 -SSA & $6.013 \pm 0.125^{\mathrm{aC}}(-35.854)$ & $4.478 \pm 0.228^{\mathrm{bB}}(-52.230)$ & $2.650 \pm 0.171^{\mathrm{cB}}(-71.730)$ \\
\hline 8-HQ & $6.138 \pm 0.109^{\mathrm{aC}}(-34.521)$ & $5.058 \pm 0.671^{\mathrm{aAB}}(-46.042)$ & $2.839 \pm 0143^{\mathrm{bB}}(-69.714)$ \\
\hline Sucrose & $6.684 \pm 0.371^{\mathrm{aBC}}(-28.696)$ & $5.257 \pm 0.100^{\mathrm{bAB}}(-43.919)$ & $3.882 \pm 0.095^{\mathrm{cA}}(-58.588)$ \\
\hline 5-SSA+Sucrose & $7.135 \pm 0.188^{\mathrm{aC}}(-23.885)$ & $5 \cdot 371 \pm 0.062^{\mathrm{bAB}}(-42.703)$ & $4.011 \pm 0.195^{\mathrm{cA}}(-57.211)$ \\
\hline 8-HQ+Sucrose & $8.958 \pm 0.410^{\mathrm{aA}}(-4.438)$ & $5.776 \pm 0.125^{\mathrm{bA}}(-38.383)$ & $4.113 \pm 0.138^{\mathrm{cA}}(-56.123)$ \\
\hline \multicolumn{4}{|c|}{ Protease activity } \\
\hline Control (DDW) & $14.721 \pm 0.048^{\mathrm{cA}}(+68.896)$ & $22.642 \pm 0.107^{\mathrm{bA}}(+159.775)$ & $28.463 \pm 0.062^{\mathrm{aA}}(+226.560)$ \\
\hline 5 -SSA & $14.310 \pm 0.082^{\mathrm{cB}}(+64.181)$ & $20.414 \pm 0.066^{\mathrm{bB}}(+134.213)$ & $27.154 \pm 0.074^{\mathrm{aB}}(+211.542)$ \\
\hline 8-HQ & $14.111 \pm 0.034^{\mathrm{cB}}(+61.898)$ & $20.115^{ \pm 0.113^{\mathrm{bC}}(+130.782)}$ & $25.332 \pm 0.090^{\mathrm{aC}}(+190.638)$ \\
\hline Sucrose & $12.365 \pm 0.111^{\mathrm{cC}}(+41.866)$ & $18.110 \pm 0.071^{\mathrm{bD}}(+107.779)$ & $23.676 \pm 0.132^{\mathrm{aD}}(+171.638)$ \\
\hline 5 -SSA+Sucrose & $10.674 \pm 0.109^{\mathrm{cD}}(+22.464)$ & $16.876 \pm 0.083^{\mathrm{bE}}(+93.621)$ & $21.881 \pm 0.136^{\mathrm{aE}}(+151.044)$ \\
\hline 8-HQ+Sucrose & $9.386 \pm 0.101^{\mathrm{cE}}(+7.687)$ & $15.421 \pm 0.114^{\mathrm{bF}}(+76.927)$ & $21.115 \pm 0.101^{\mathrm{aF}}(+142.256)$ \\
\hline
\end{tabular}

Means with different lower case letters in the same row are statistically $(\mathrm{P} \leq 0.05)$ different (i.e. according to days using DMRT).

Means with different upper case letters in the column of same box are statistically $(\mathrm{P} \leq 0.05)$ different (i.e. according to treatments using DMRT).

Data in parenthesis indicate percent change from the initial (o-Day) value. 
Table 6. Matricaria parthenium L. showing changes in the amount of protein (mg / $100 \mathrm{mg}$ dry weight \pm S.E.) and protease activity ( $\mu \mathrm{M}$ Lysine equivalent / $100 \mathrm{mg}$ dry weight \pm S.E.) in petals when scapes were placed in various holding solutions (Double distilled water, DDW as control; 5-sulfosalicylic acid, 5-SSA, 200 ppm; 8hydroxyquinoline, 8-HQ, $200 \mathrm{ppm}$; sucrose, o.1M; 5-SSA, $200 \mathrm{ppm}+$ sucrose, o.1M; 8-HQ, $200 \mathrm{ppm}+$ sucrose, $0.1 \mathrm{M})$. [o-day values of protein and protease activity were $11.042 \pm 0.728$ and $7.343 \pm 0.054$ respectively].

\begin{tabular}{|c|c|c|c|}
\hline Treatments & 2-Day & 4-Day & 6-Day \\
\hline \multicolumn{4}{|c|}{ Protein } \\
\hline Control (DDW) & $8.142 \pm 0.415^{\mathrm{aC}}(-26.263)$ & $6.901 \pm 0.199^{\mathrm{bB}}(-37.502)$ & $3.992 \pm 0.201^{\mathrm{cC}}(-63.847)$ \\
\hline 5-SSA & $8.332 \pm 0.161^{\mathrm{aC}}(-24.543)$ & $7.213 \pm 0.241^{\mathrm{bAB}}(-34.677)$ & $4.827 \pm 0.258^{\mathrm{cBC}}(-56.285)$ \\
\hline 8-HQ & $8.492 \pm 0.162^{\mathrm{aC}}(-23.094)$ & $7.440 \pm 0.172^{\mathrm{bAB}}(-32.621)$ & $5.328 \pm 0.244^{\mathrm{cAB}}(-51.748)$ \\
\hline Sucrose & $9.809 \pm 0.434^{\mathrm{aB}}(-11.166)$ & $7.479 \pm 0.251^{\mathrm{bAB}}(-32.268)$ & $5.708 \pm 0.150^{\mathrm{cAB}}(-48.306)$ \\
\hline 5-SSA+Sucrose & $10.320 \pm 0.414^{\mathrm{aAB}}(-6.539)$ & $7.691 \pm 0.347^{\mathrm{bAB}}(-30.348)$ & $5.977 \pm 0.273^{\mathrm{cA}}(-45.870)$ \\
\hline 8-HQ+Sucrose & $10.915 \pm 0.183^{\mathrm{aA}}(-1.150)$ & $8.072 \pm 0.449^{\mathrm{bA}}(-26.897)$ & $6.345 \pm 0.647^{\mathrm{cA}}(-42.538)$ \\
\hline \multicolumn{4}{|c|}{ Protease activity } \\
\hline Control (DDW) & $16.680 \pm 0.088^{\mathrm{cA}}(+127.155)$ & $23.644 \pm 0.076^{\mathrm{bA}}(+221.994)$ & $31.389 \pm 0.066^{\mathrm{aA}}(+327.468)$ \\
\hline 5 -SSA & $16.093 \pm 0.036^{\mathrm{cB}}(+119.161)$ & $21.312 \pm 0.037^{\mathrm{bB}}(+190.236)$ & $30.214 \pm 0.05^{\mathrm{aB}}(+311.467)$ \\
\hline 8-HQ & $15.618 \pm 0.074^{\mathrm{cC}}(+112.692)$ & $20.531 \pm 0.047^{\mathrm{bC}}(+179.600)$ & $29.316 \pm 0.048^{\mathrm{aC}}(+299.237)$ \\
\hline Sucrose & $14.131 \pm 0.057^{\mathrm{cD}}(+92.442)$ & $18.125 \pm 0.05^{6 \mathrm{bD}}(+146.834)$ & $26.651 \pm 0.062^{\mathrm{aD}}(+262.944)$ \\
\hline 5-SSA+Sucrose & $12.246 \pm 0.018^{\mathrm{cE}}(+66.771)$ & $16.845 \pm 0.079^{\mathrm{bE}}(+129.402)$ & $24.772 \pm 0.059^{\mathrm{aE}}(+237.355)$ \\
\hline 8-HQ+Sucrose & $10.196 \pm 0.027^{\mathrm{cF}}(+38.853)$ & $16.110 \pm 0.027^{\mathrm{bF}}(+119.393)$ & $22.262 \pm 0.038^{\mathrm{aF}}(+203.173)$ \\
\hline
\end{tabular}

Means with different lower case letters in the same row are statistically $(\mathrm{P} \leq 0.05)$ different (i.e. according to days using DMRT).

Means with different upper case letters in the column of same box are statistically $(\mathrm{P} \leq 0.05)$ different (i.e. according to treatments using DMRT).

Data in parenthesis indicate percent change from the initial (o-Day) value.

Table 7. Gaillardia pulchella Foug. showing changes in the amount of protein (mg / $100 \mathrm{mg}$ dry weight \pm S.E.) and protease activity ( $\mu \mathrm{M}$ Lysine equivalent / $100 \mathrm{mg}$ dry weight \pm S.E.) in petals when scapes were placed in various holding solutions (Double distilled water, DDW as control; 5-sulfosalicylic acid, 5-SSA, 200 ppm; 8hydroxyquinoline, 8-HQ, $200 \mathrm{ppm}$; sucrose, o.1M; 5-SSA, $200 \mathrm{ppm}+$ sucrose, o.1M; 8-HQ, $200 \mathrm{ppm}+$ sucrose, $0.1 \mathrm{M})$. [o-Day values of protein and protease activity were $6.862 \pm 0.062$ and $4.550 \pm 0.050$ respectively].

\begin{tabular}{|c|c|c|c|}
\hline Treatments & 2-Day & 4-Day & 6-Day \\
\hline & \multicolumn{3}{|c|}{ Protein } \\
\hline Control (DDW) & $4.032 \pm 0.055^{\mathrm{aE}}(-41.242)$ & $2.208 \pm 0.004^{\mathrm{bD}}(-67.823)$ & $0.436 \pm 0.004^{\mathrm{cD}}(-93.646)$ \\
\hline 5 -SSA & $4.446 \pm 0.064^{\mathrm{aD}}(-35.208)$ & $2.898 \pm 0.082^{\mathrm{bC}}(-57.767)$ & $1.226 \pm 0.122^{\mathrm{cC}}(-82.133)$ \\
\hline 8-HQ & $4.511 \pm 0.044^{\mathrm{aD}}(-34.261)$ & $3.094 \pm 0.158^{\mathrm{bBC}}(-54.911)$ & $1.521 \pm 0.143^{\mathrm{cBC}}(-77.834)$ \\
\hline Sucrose & $4.804 \pm 0.015^{\mathrm{aC}}(-29.991)$ & $3.362 \pm 0.079^{\mathrm{bB}}(-51.006)$ & $1.767 \pm 0.065^{\mathrm{cAB}}(-74.249)$ \\
\hline 5-SSA+Sucrose & $5.391 \pm 0.162^{\mathrm{aB}}(-21.437)$ & $3.746 \pm 0.085^{\mathrm{bA}}(-45.410)$ & $1.923 \pm 0.139^{\mathrm{cA}}(-71.976)$ \\
\hline 8-HQ+Sucrose & $5.997 \pm 0.072^{\mathrm{aA}}(-12.606)$ & $3.992 \pm 0.143^{\mathrm{bA}}(-41$. & $2.040 \pm 0.056^{\mathrm{cA}}(-70.271)$ \\
\hline \multicolumn{4}{|c|}{ Protease activity } \\
\hline Control (DDW) & $11.563 \pm 0.087^{\mathrm{CA}}(+154.132)$ & $18.771 \pm 0.042^{\mathrm{bA}}(+312.549)$ & $27.157 \pm 0.091^{\mathrm{aA}}(+496.857)$ \\
\hline 5 -SSA & $10.632 \pm 0.051^{\mathrm{cB}}(+133.670)$ & $18.130 \pm 0.052^{\mathrm{bB}(}(+298.462)$ & $25.312 \pm 0.019^{\mathrm{aB}}(+456.308)$ \\
\hline 8-HQ & $9.253 \pm 0.049^{\mathrm{cC}}(+103.363)$ & $17.234 \pm 0.030^{\mathrm{bC}}(+278.769)$ & $24.621 \pm 0.039^{\mathrm{aC}}(+441.121)$ \\
\hline Sucrose & $7.680 \pm 0.044^{\mathrm{cD}}(+68.791)$ & $15.625 \pm 0.064^{\mathrm{bD}}(+243.407)$ & $22.110 \pm 0.078^{\mathrm{aD}}(+385.934)$ \\
\hline 5-SSA+Sucrose & $5.545 \pm 0.04 \mathrm{O}^{\mathrm{cE}}(+21.868)$ & $14.821 \pm 0.057^{\mathrm{bE}}(+225.736)$ & $20.320 \pm 0.064^{\mathrm{aE}}(+346.593)$ \\
\hline 8-HQ+Sucrose & $4.990 \pm 0.039^{\mathrm{cF}}(+9.670)$ & $12.370 \pm 0.073^{\mathrm{bF}}(+171.868)$ & $19.123 \pm 0.033^{\mathrm{aF}}(+320.286)$ \\
\hline \multicolumn{4}{|c|}{$\begin{array}{l}\text { Means with different lower case letters in the same row are statistically }(\mathrm{P} \leq 0.05) \text { different (i.e. according to days } \\
\text { using DMRT). } \\
\text { Means with different upper case letters in the column of same box are statistically }(\mathrm{P} \leq 0.05) \text { different (i.e. } \\
\text { according to treatments using DMRT). } \\
\text { Data in parenthesis indicate percent change from the initial (o-Day) value. }\end{array}$} \\
\hline
\end{tabular}

M. Khokhar et al. (2020) / Comparative assessment of sucrose, 8-hydroxyquinoline and 5-sulfosalicylic acid in the regulation 


\section{Discussion}

Results presented above indicate that individual application of 8-HQ (a biocide), 5-SSA (a plant growth regulator) and sucrose (a metabolite) and a combined treatment of $8-\mathrm{HQ}+$ sucrose as well as 5 -SSA + sucrose are very effective in reducing the shrinkage of flower diameter, and increasing the moisture content and longevity of all cut flowers investigated. The most promising holding solution is 8-HQ with sucrose in all three plants under investigation. When freshly cut scapes are placed in holding solutions, they gradually show shrinkage and decrease in flower diameter as observed in cut scapes of Iris germanica, Hemerocallis fulva and Petunia hybrida (Gulzar, 2003). Moisture content was maximum at the time of flower opening and it declined after transferring cut scapes to holding solutions irrespective of their specific nature.

Working with cut roses, Kumar and Pal (2005) have shown maximum vase life when $50 \mathrm{ppm}$ of 8hydroxyquinoline citrate (8-HQC) was used. Chrysanthemum cut flowers exhibited maximum vase life, solution uptake and flower size with $2 \%$ sucrose +200 ppm $8-\mathrm{HQC}$ in comparison to water as control (Verma et al., 2007). Bacterial proliferation is responsible for the vascular blockage in cut flowers (Halevy and Mayak, 1979; van Doorn et al., 1989). It appears that sucrose, 8HQ and 5-SSA have improved the water uptake of cut flowers by reducing the vascular blockage as one of these chemicals (8-HQ) is known to possess strong anti-microbial properties that eliminate vascular blockage resulting greater water uptake (Burdett, 1970).

Hydroxyquinolines (8-HQ, 8-hydroxyquinoline; 8HQC, 8-hydroxyquinoline citrate and 8-HQS, -8hydroxyquinoline sulphate) are responsible for rendering the holding solution acidified so that bacterial growth is reduced remarkably.

Another study with Gladiolus grandiflora (Ezhilmathi et al., 2007) using 5-SSA has shown significant increment in the uptake of vase solutioin, vase life and number of open florets as compared with control sets. They have also extended flower vase life using a combination of $100 \mathrm{ppm} 5$-SSA and $4 \%$ sucrose in 1:1 ratio. In cut carnation flowers, a combination of sugar and cytokinin were able to improve the longevity and performance in comparison to that situation where only one of these chemicals was present (van Staden et al., 1990). Combined applications of kinetin + sucrose and SA + sucrose were shown to be effective in arresting partly the reduction in flower diameter in Aster novae belgii (Mukherjee and Mukherjee, 2020). Sucrose is the source of energy and respiratory substrate which improves the ability of the tissue to absorb water and maintains turgidity (Bhaskar et al., 1999; Pun and Ichimura, 2003; Varu and Barad, 2008).

As far as alteration in the quantity of protein is concerned, individually 5-SSA and 8-HQ were slightly effective in minimizing the loss by lowering the protease activity in petals of cut scapes of $A$. novae belgii, $M$. parthenium and $G$. pulchella. Sucrose was a little more effective than other two compounds. Petal senescence has been associated with loss of protein as noticed in many plants including Dianthus caryophyllus (Kenis et al., 1985; Sugawara et al., 2002), cut daylily flowers (Lay-Yee et al., 1992), Alstroemeria (Wagstaff et al., 2002), Iris (Pak and van Doorn, 2005), Petunia (Jones et al., 2005) and gladiolus (Azeez et al., 2007). The rapid decline is due to little amount of de novo synthesis and considerable protein degradation (Lay-Yee et al., 1992). This leads to membrane disintegration (Woolhouse, 1984). Present study has noticed very high protease activity responsible for this breakdown. Combined applications of $8-\mathrm{HQ}+$ sucrose and 5-SSA + sucrose were much more effective than their individual application as revealed in the present study. Shiva et al. (2002) found the effectiveness of 8 -HQC (150 ppm) with sucrose (3\%) in cut roses while Ezhilmathi et al (2007) found the importance of 5-SSA + sucrose in earlier studies. Studies carried out in our laboratory revealed efficacious nature of SA in Calendula officinalis (Renu et al., 2018) and 8-HQ in C. officinalis and Gaillardia pulchella (Mukherjee et al., 2019).

\section{Conclusion}

Among individual treatments, sucrose (o.1M) as a metabolite in the holding solution was the best followed by 8 -HQ (200 ppm, a biocide) and 5-SSA (200 ppm, a PGR) in reducing petal shrinkage and minimizing moisture loss. Combined application was much better than individual treatment, the 
best being 8-HQ + sucrose in cut scapes of all selected plants viz. A. novae belgii, $M$. parthenium and G. pulchella. Protein degradation was also effectively controlled by these treatments in comparison to control; the degree of competence was 8-HQ + sucrose $>5-\mathrm{SSA}+$ sucrose $>$ sucrose $>$ 8-HQ $>$ 5-SSA > control.

\section{Conflict of interest statement}

Authors declare that they have no conflict of interest.

\section{Acknowledgement}

The financial assistance to D. Mukherjee from Indian Science Congress Association, Kolkata for providing Asutosh Mookerjee Fellowship is gratefully acknowledged. Authors are also grateful to Chairperson, Department of Botany, Kurukshetra University, Kurukshetra for laboratory facilities.

\section{References}

Azeez, A., Sane, A.P., Bhatnagar, D., Nath, P., 2007. Enhanced expression of serine proteases during floral senescence in gladiolus. Phytochemistry. 68, 1352-1357.

Beevers, L., 1976. Senescence. In : Plant Biochemistry (Eds. : Bonner, J., Varner, J.E.), Academic Press, New York, San Francisko and London, pp. 771-794.

Bhaskar, V.V., Rao, P.V., Reddy, Y.N., 1999. Effects of minerals on the post harvest vase life of cut tuberose (Polianthes tuberosa L.) cv. Double. Indian J. Hort. 56, 368-374.

Bradford, M.M., 1976. A rapid and sensitive method for the quantitation of microgram quantities of proteins utilizing the principle of protein-dye binding. Anal. Biochem. 72, 248254.

Buchanan - Wollaston, V., 1997. The molecular biology of senescence. J. Exp. Bot. 48, 191199.

Burdett, A.N., 1970. The cause of bent neck in cut roses. J. Amer. Soc. Hort. Sci. 95, 427-431.

Ezhilmathi, K., Singh, V.P., Arora, A., Sairam, R.K., 2007. Effect of 5-sulfo- salicylic acid on antioxidant activity in relation to vase life of Gladiolus cut flowers. Plant Growth Regul. 51, 99-108.
Gulzar, S., 2003. Studies on post harvest physiology and vase life in some selected ornamental flowers. M.Phil. dissertation, The University of Kashmir, Srinagar.

Halevy, A.H., Mayak, S., 1979. Senescence and postharvest physiology of cut flowers. Part 1. Hortic. Rev. 1, 204-236.

Jones, M.L., Chaffin, G.S., Eason, J.R., Clark, D.G., 2005. Ethylene sensitivity regulates proteolytic activity and cysteine protease gene expression in petunia corollas. J. Exp. Bot. 56, 27332744.

Jowkar, M.M., Kafi, M., Khalighi, A., Hasanzadeh, N., 2012. Postharvest physiological and microbial impact of hydroxyquinoline citrate as 'Cherry Brandy' rose vase solution biocide. Ann. Biol. Res. 3, 2238-2247.

Kaur, P., Mukherjee, S., Mukherjee, D., 2017. Physiology of cut flowers and senescence regulation. Trends Biosci. 10, 9226-9232.

Kenis, J.D., Silvente, S.T., Trippi, V.S., 1985. Nitrogen metabolism and senescence associated changes during growth of carnation flowers (Dianthus caryophyllus). Physiol. Plant. 65, 455-459.

Khokhar, M., Mukherjee, S., Mukherjee, D., 2018. Senescence regulation in petals of Calendula officinalis L. cut flowers with sucrose, kinetin, salicylic acid and a morphactin. Trends Biosci. 11, 1938-1944.

Kuiper, D., Ribot, S., van Reenen, H.S., Marrissen, N., 1995. The effect of sucrose on the flower bud ripening of 'Madelon' cut roses. Scien. Hort. 60, 325-336.

Kumar, J., Pal, K., 2005. Response of certain chemicals on postharvest quality of rose flowers. J. Ornamental Hort. 8, 316-317.

Lay-Yee, M., Stead, A.D., Reid, M.S., 1992. Flower senescence in daylily (Hemerocallis). Physiol. Plant. 86, 308-314.

Monteiro, J.A., Nell, T.A., Barrett, J.E., 2002. Effects of exogenous sucrose on carbohydrates levels, flower respiration and longevity of potted miniature rose (Rosa hybrida) flowers during post production. Postharvest Biol. Technol. 26, 221-229.

Mukherjee, S., Mukherjee, D., 2017. Additive effects of sucrose with kinetin and salicylic acid in delaying petal senescence of cut flowers of Matricaria parthenium L. Int. J. Curr. Res. Biosci. Plant Biol. 4 (11), 86- 95.

Mukherjee, S., Singh, S., Jakhar, S., Mukherjee, D., 
2019. Postharvest regulation of petal senescence in Gaillardia pulchella Foug. scapes by sucrose, 8-hydroxyquinoline and methylchlorflurenol individually and in combination as vase solution. J. Indian Bot. Soc. 98(1), 37-44.

Mukherjee, S., Mukherjee, D., 2020. Individual effects of sucrose, kinetin and salicylic acid and combined effects of kinetin + sucrose and salicylic acid + sucrose in petal senescence regulation of Aster novae belgii L. Int. J. Curr. Res. Biosci. Plant Biol. 7(2), 14-21.

O'Donoghue, E.M., Somerfield, S.D., Heyes, J.A., 2002. Vase solutions containing sucrose result in changes to cell walls of Sandersonia (Sandersonia aurantiaca) flowers. Postharvest Biol. Technol. 26, 285-294.

Pak, C., van Doorn, W.G., 2005. Delay of Iris flower senescence by protease inhibitors. New Phytol. 165, 473-480.

Pun, U.K., Ichimura, K., 2003. Role of sugars in senescence and biosynthesis of ethylene in cut flowers. JARQ. 34, 219-224.

Rabiza-Swider, Julita., Skutnik, Ewa., Chodorska, Maria., 2012. The effect of growth regulators and preservative on senescence of cut oriental Lily 'Helvetia'. Acta Sci. Pol. Hortorum Cultus. 11, 183-194.

Raskin, I., 1992. Role of salicylic acid in plants. Annu. Rev. Plant Physiol. Plant Mol. Biol. 43, 439-463.

Reimerdes, E.H., Klostermeyer, H., 1976. Determination of proteolytic activities on casein substrates. Methodology in Enzymology. 45, 26-28.

Renu, Jakhar, S., Mukherjee, D., 2018. Pre-harvest and post-harvest applications of salicylic acid and methylchlorflurenol to modify petal senescence in Calendula officinalis L. Int. J. Res. Appl. Sci. Eng. Technol. 6(10), 624-634.

Shiva, K.N., Chatterjee, S.R., Bhattacharjee, S.K., 2002. Effect of pulsing and wet storage on changes in the contents of total free amino acids and protein during senescence of cut rose. The Orissa J. Hort. 30, 30-34.

Singh, S., Mukherjee, S., Jakhar, S., Mukherjee, D., 2018. Interaction of sucrose, a morphactin and 8-hydroxyquinoline in the regulation of petal senescence of Calendula officinalis L. cut flowers. Int. J. Curr. Res. Biosci. Plant Biol. 5(12), 28-38.

Stead, A.D., van Doorn, W.G., 1994. Strategies of flower senescence: a review. In: Molecular and Cellular Aspect of Plant Reproduction (Eds.: Scott, R.J., Stead, A.D.), Cambridge University Press, Cambridge, pp. 215-238.

Sugawara, H., Shibuya, K., Yoshioka, T., Hashiba, T., Satoh, S., 2002. Is cysteine proteinase inhibitor involved in the regulation of the petal wilting in senescing carnation (Dianthus caryophyllus) flowers? J. Exp. Bot. 53, 407413.

van Doorn, W.G., 2004. Is petal senescence due to sugar starvation? Plant Physiol. 134, 35-42.

van Doorn, W.G., Schurer, K., De Witte, Y., 1989. Role of endogenous bacteria in vascular blockage of cut rose flowers. J. Plant Physiol. 134, 371-381.

van Doorn, W.G., Perik, R.R.J., 1990. Hydroxyquinoline citrate and low $\mathrm{pH}$ prevent vascular blockages in stems of cut rose flowers by reducing the number of bacteria. J. Amer. Soc. Hort. Sci. 115, 979-981.

van Doorn, W.G., Woltering, E.J., 2008. Physiology and molecular biology of petal senescence. J. Exp. Bot. 59, 453-480.

van Staden, J., Bayley, A.D., Upfold, S.J., Drewes, F.E., 1990. Cytokinins in cut carnation flowers. VIII. Uptake, transport and metabolism of benzyladenine and the effect of benzyladenine derivatives on flower longevity. J. Plant Physiol. 135, 703-707.

Varu, D.K., Barad, A.V., 2008. Effect of harvesting date and floral preservatives on vase life of tuberose (Polianthes tuberosa L.) cut flowers during winter season. J. Ornamental Hort. 11, 181-187.

Verma, A.K., Gupta, Y.G., Dhiman, S.R., Thakur, K.S., 2007. Influence of nitrogen and potassium levels and holding solutions on post harvest quality of chrysanthemum (Dendranthema grandiflora Tzvelev.) cut flowers. J. Ornamental Hort. 10, 222-228.

Wagstaff, C., Leverentz, M.K., Griffiths, G., Thomas, B., Chanasut, U., Stead, A.D., Rogers, H.J., 2002. Cysteine protease gene expression and proteolytic activity during senescence of Alstroemeria petals. J.Exp. Bot. 53, 233-240.

Woltering, E.J., van Doorn, W.G., 1988. Regulation of ethylene in senescence of petals: morphological and taxonomic relationship. J. Exp. Bot. 39, 1605-1616.

Woolhouse, H.W., 1967. The nature of senescence in plants. Sym. Soc. Exp. Biol. 21, 179-214. 
Woolhouse, H.W., 1984. The biochemistry and regulation of senescence in chloroplasts. Can. J. Bot. 62, 2934-2942.
Yemm, E.W., Cocking, E.C., 1955. The determination of amino acids with ninhydrin. Analyst. 80, 209-213.

\section{How to cite this article:}

Khokhar, M., Mukherjee, S., Mukherjee, D., 2020. Comparative assessment of sucrose, 8hydroxyquinoline and 5-sulfosalicylic acid in the regulation of petal senescence in cut scapes of Aster novae belgii L., Matricaria parthenium L. and Gaillardia pulchella Foug. Int. J. Curr. Res. Biosci. Plant Biol. 7(11), 14-24. doi: https://doi.org/10.20546/ijcrbp.2020.711.002 